Toto Giusi Antonia,

Ph D., in Culture, Education, Communication, Department of humanities. Literature, Cultural Heritage

University of Foggia,

E-mail:giusy.toto@unifg.it

Strazzeri Irene,

Assistant Professor, of General Sociology,

Department of humanities. Literature, Cultural Heritage

University of Foggia,

E-mail: irene.strazzeri@unifg.it

\title{
NEW TENDENCIES OF SOCIOLOGY OF ART: FROM THE COMMUNICATIVE AND ECONOMIC READINGS TO THE CONTEMPORARY RESEARCH OF SCIENTIFICITY
}

\begin{abstract}
The aim of the paper is to look for new trends in sociological research in the arts, especially in terms of new research perspectives and new research objects.

Keywords: Sociology of art, sociological research, art perspectives, interdisciplinary approach.

The research interests of contemporary sociology are being redefined and are being enriched with new and renewed research objects. Among these the study of art, literature and music has come back into vogue as unusual fields of sociological investigation. The sociology of art, considering the wide way the concept of artistic product, has recently obtained a space of autonomy within the sociological research. From its origins, referring in particular to the Sociology of Music of Weber (1921) [1] or of Adorno (1962) [2], the sociology of art has investigated the relationship between artistic product (in the two cases mentioned the music) and social world, and still, the relations between diffusion and consumption. A strong impulse to the sociological investigation took place in the 1960s, when in the United States, almost simultaneously with the publication of the Adorno' Introduction to the Musical Sociology in 1962, an article by Robert Nisbet entitled Sociology as Art form appeared in the journal "The Pacific Sociological Review". This article marks an epochal turning point, in fact the author states that: "sociological science makes its most significant intellectual progress under

the spur of stimuli and processes that it shares widely with art and that, beyond their differences, science and art have in common above all the ability to discover and the ability to create" $[3,2]$. This approach between Sociology and Art has undergone the beginning of the 80 s of the last century a contamination between the nascent sociology of art and other disciplines such as anthropology, the history of literature, music and the arts and even studies on subcultures proceeding towards new hermeneutical and interdisciplinary paths. Even more recent Heinich's studies (2002) have mixed the classic aesthetic interpretive canons of philosophy, with the contemporary sociological, communicative and economic readings of the artistic event $[4,11-12]$.

Today, the Sociology of Art explores social tensions, the multiplicity of discrimination and the related strategies of resistance, the conflicting dynamics underlying artistic products. Art as a symbolic construction of meaning, becomes the 'mirror' of civil society and of the class struggle, the temple of memory and the social frame of interpretation of gender identities and racial discrimination. Art and
\end{abstract}


Society, Art and Sociological Science influence each other and co-construct, mixing knowledge, stories and images full of symbolic meanings [5, 78-79]. There are two fundamental components in contemporary sociological research applied to art: the object of research and new investigative and interpretative methods. In this context it is interesting the position of Howard Berker [6,200-206], who indicates in the history of the work, the sociological perspective to follow. According to this author it is interesting to reconstruct all the choices and decisions that the artist makes. In the case of collective works, typical of contemporary works (music, cinema, etc.), it is necessary to investigate the choices of the various people or groups involved and how they have resolved the decisional conflicts, to analyze new dimensions of the creation of the artistic product. From a methodological point of view, which is already evident in the analysis of the artistic product just described, also where to begin to tell the story of the artistic product is important, since there is always something that comes before or after that can be interesting to purposes of sociological analysis, therefore the recognition of the arbitrariness of the observer's analysis becomes a necessary prerequisite. In the sociological study of the production processes, if there are contracts upstream of the work of art, they are usually circumvented or broken because the artistic discipline is creativity. This universal principle is more visible in contemporary works, because the break is the artistic canon [7,200-206].

Sociology, when dealing with art, traditionally follows a functionalist approach, that is, it explains what is the function of art in society, which is born between relationships and constructions of meaning. Art, instead, is the result of negotiation between the author and the public, from a constructivist point of view. In artistic performances macro-cosmos are created in which the social order is preserved and the maintenance of culture is sponsored. In contemporary times, art becomes dematerialized and strongly symbolic, so much so as to virtually express its inno- vative potential that makes societies open to change. One of the founding themes in sociology is conflict, as it occurs between groups not only for claims of social rights, but also, as in this case, in the interaction between professionals, between the author and the public, or with the commissioners [8, 200-206]. Today, the struggles on the division of income from a work of art are more complex because they are associated with internet marketing, with the general ability to facilitate the copying of works (art, music or film). Again, sometimes, the work of art can be interpreted from an aesthetic point of view also through moral judgment or the interest of the public, until reaching a degree of interpretation based on the diffusion of the artistic product, free from any commercial pressure $[9,200-206]$. This last concept refers to the degree of sharing that a product has with the public that uses it, the greater the sharing, the greater the communicativeness of the product beyond any aesthetic judgment. In addition to dematerialization another important concept is durability understood as duration in the physical sense, it is a contingency that affects all the work. The duration depends on the choices made by a large number of people. The protection, safeguard, preservation of the artistic heritage for future generations are intimately connected to the value that each company attributes to art [10, 200-206]. In this discourse of protection the revival theme also takes on importance, which stems from the motivation to 'revive' work or an artistic object.

Artistic work, like the scientific one, can be written in several hands, rewritten in different periods and subject to multiple interpretations. Art as a product and producer of social relations becomes, thanks to the virtual, a fundamental element that triggers processes of change in the existing order [11,200-206]. The main challenges for future social research in the arts, not as autonomous knowledge but as a declination of the more general sociological discourse, are on the one hand the identification of specific areas of investigation and specific objects of study, to be defined within the boundaries fluids, which today 
characterize the discipline, on the other the inevitable contamination of different skills, due to the variability and the multiplicity of artistic languages. Faced with this plurality it becomes necessary to make methodological and conceptual choices that characterize scientifically the analysis of data coming from a field of investigation, which is incomprehensibly underestimated [12, 200-206]. Postmodernism and contemporary globalization have transformed the role of art; it becomes the seat of deconstruction and the conceptualization of meanings. The concept of art romanticism is being challenged today, thanks to the sociological perspectives of reading the works. The work of art, in fact, is not considered a work of genius and therefore universal, but the result of pro- duction processes, artistic fruition and litmus test of current social conflicts. Theories of the reception of the works opened the way to the sociological theories of the social dynamics underlying the works of art and contextual theories. These last theories study how the process of fruition of the work of art is oriented by the context, that is, by the social processes that build the artistic values shared by the community. They provide a very interesting point of view because they focus their analysis on the success of a work of art; according to the reception theory, success arises from a cooperation between artist and recipient, for contextual theories, on the other hand, the recognition of artistic value passes through social practices $[13,200-206]$.

\section{References:}

1. Weber M. Sociologia della musica. Milano: Il Saggiatore.- 2017. (posthumous original edition of the 1921). $-183 \mathrm{p}$.

2. Adorno T.W. Introduzione alla sociologia della musica. Torino: Einaudi.- $1962 .-823$ p.

3. Nisbet R. A. Sociologia e Arte, Milano-Udine: Mimesis.-2016.- 59 p.

4. Heinich N. La sociologie de l'art. Parigi: La Decouverte.- 2002.- 123 p.

5. Savonardo L. Sociologia della Musica. Novara, Utet.- 2014.- 288 p.

6. Becker H. Novas direções na Sociologia da Arte // Plural (São Paulo. Online).- No. 24.2.- 2018.P. 200-206.

7. Tota A.L. Etnografia dell'arte: per una sociologia dei contesti artistici. Milano: Ledizioni.-2011.-222 p.

8. Bordoni C. Introduzione alla sociologia dell'arte. Liguori Editore. -2008 . -280 p.

9. Ferone E. Segni dei Tempi: La costruzione delle regole in un mondo globale ed intangibile (Vol. 1). Bologna: Società Editrice Esculapio. - 2016. - 168p.

10. Viviani D. Struttura e forma sociale: un legame estetico / / Sociologia. Rivista quadrimestrale di Scienze Storiche e Sociali-Culture politiche in mutamento.- No. 1/ - 2014. Gangemi Editore spa.

11. Gemini L. L'incertezza creativa: i percorsi sociali e comunicativi delle performance artistiche - Vol. 9.Milano: FrancoAngeli.- 2003.- 193 p.

12. Clammer J. Vision and Society: Towards a sociology and anthropology from art. Londra. Routledge.2014. $-238 \mathrm{p}$.

13. Giuliano V. Patrimonio al futuro. Un manifesto per i beni culturali e il paesaggio.- Milano. Electa.-2015. $178 \mathrm{p}$. 